\title{
Aspekte van Tydreëling in Normale en Verbaal-apraktiese Spraak
}

\author{
Matilda de Jager, B(Log) (Pretoria) \\ Departement Spraakheelkunde en Oudiologie, Universiteit van Pretoria
}

\section{OPSOMMING}

Die doel van hierdie ondersoek is om inligting te verkry in verband met' $n$ aspek van tydreëling van spraakproduksie, naamlik segmentele tydsduur in Afrikaans. Vier normale sprekers en 'n apraktiese spreker is as proefpersone gebruik. Uit die resultate blyk dit dat daar wel temporale reëls in Afrikaans voorkom. Deur segmentele tydsduur by die apraktiese spreker te bestudeer, kan verdere insig in die afwyking asook terapieleidrade verkry word.

\section{ABSTRACT}

The aim of this research report is to obtain information concerning an aspect of timing of speech production, namely, the duration of speech segments in Afrikaans. Four normal speakers and an apraxic speaker were used as subjects. From the results obtained it is evident that timing rules do exist in Afrikaans. By analyzing the productions of the apraxic speaker in terms of segmental duration, more insight into this disorder, as well as therapeutic guidelines can be obtained.

Huidige kennis oor temporale organisasie of tydreëling van spraak is hoofsaaklik gegrond op studies wat uitgevoer is in Engels. Omdat daar nog geen studies in die verband in Afrikaans gedoen is nie, bestaan daar 'n groot behoefte aan inligting omtrent die toepassing van tydreëling deur normale Afrikaanssprekende persone.

Tydreëling is een van die twee belangrikste komponente van die beplanning of programmering van spraak. Motoriese kontrole vir spraakaksies vereis dus akkommodasie en koördinasie in tyd en ruimte van die artikulatoriese gebeure vir die produksie van opeenvolgende segmente in die spraakketting (Löfquist \& Yoshioka, 1981). Verskeie navorsers het die belang van temporale inligting as deel van die gestoor de motorprogram vir spraakaksies gedemonstreer (Cooper \& Allen, 1977). Volgens Bell-Berti en Harris (1981) het vroeëre modelle van spraakproduksie nie daarin geslaag om wel spraakproduksie te verklaar nie, juis omdat dit tydreëling beskou het as 'n byproduk

(C) SASHA 1986 van artikulatoriese gebeure in plaas van as ' $n$ integrale organiserende parameter van motoriese spraakbeplanning.

Die aspek van tydreëling wat in hierdie studie ondersoek word, is segmentele tydsduur. Navorsing in verband met segmentele tydsduur lê veral klem op 3 aspekte. Die eerste aspek is kontekstuele invloed op segmentele tydsduur. Volgens DiSimoni (1974 a) is die kontekstuele invloed op segmentele tydsduur deel van die tydreëlingsisteem van elke taal en word dit aangeléer deur die sprekers van die taal. Die tweede aspek is temporale kompensasie, met ander woorde die effek wat inwerk om die duur van die interne segmente van artikulatoriese eenhede te modifieer in herhaalde produksies. Temporale kompensasie is ook nie 'n eienskap van alle tale nie (DiSimoni 1974 b) en die feit dat dit eers na 9 jaar ten volle aangeleer is, dui daarop dat ontwikkeling plaasvind tot ' $n$ volwasse gesofisitikeerde, akkurate tydreëlingsmeganisme. Die derde aspek is die invloed van die konsonantkombinasie (kk) op segmentele tydsduur binne eenlettergrepige woorde. Uit navorsing gedoen, blyk dit 
dat daar ' $n$ temporale reël in Engels is met betrekking tot KKverkorting, naamlik dat die duur van die $\mathrm{KV}^{*}$ in ' $\mathrm{n}$ KVK-en KVKK-eenheid ongeveer dieselfde bly in verhouding tot die totale duur ten spyte van die feit dat die KV en KVK twee derdes en in KVKK in werklikheid die helfte van die totale uiting uitmaak (Walsh 1984). Uit al bogenoemde blyk dit dus dat reëls en opsigte van aspekte van segmentele tydsduur verband hou met 'n spesifieke taal. Dit sou interessant wees om ondersoek in te stel na die voorkoms daarvan in Afrikaans.

Kennis oor tydreëling kan ook as basis dien vir navorsing oor neuromotoriese spraakafwykings, byvoorbeeld verworwe verbále apraksie. Volgens Kent en Rosenbek (1983) is verbale apraksie 'n programmeringsafwyking wat 'n afwyking in tydreëling en koördinasie tot gevolg het. Die siening dat tydreëlingsabnormaliteite apraktiese spraak kenmerk, hou dus belofte in vir die begrip van die afwyking. Uit studies gedoen deur Freeman, Sands en Leavitt (Collins, Rosenbek \& Wertz, 1983) en Collins et al. (1983) blyk dit dat reëls in verband met duurverhoudings behoue bly by die apraktiese spreker alhoewel produksie wel uitermate verleng word, relatief tot normale produksie. Daar bestaan egter ook teenstrydige studies oor duurverhoudings by apraktiese sprekers (Bauman, Wangler \& Prescott in Collins et al. (1983); DiSimoni en Darley 1977). Collins, Rosenbek en Wertz (1983) voel dus dat verdere ondersoek na bogenoemde verskynsels benodig word en dat voortgesette studie van vokaal-konsonant- en lettergreepduur nodig is om die huidige bevindinge oor apraksie te bekragtig.

Hierdie studie is dus 'n eerste poging om 'n aspek van tydreëling, naamlik segmentele tydsduur in Afrikaans by normale en verbaal-apraktiese persone te bestudeer. Daar sal gepoog word om inligting te bekom in verband met aspekte van tydreëling in Afrikaanse eenlettergrepige woorde van KVK- en KVKKstruktuur ten einde afleidings te maak ten opsigte van temporale reëls in Afrikaans. Deur die aard van die verskil en oreenkomste tussen normaalsprekendes en 'n apraktiese spreker ten opsigte van bogenoemde te bestudeer, kan verfynde beskrywing van segmentele tydsduur by verworwe verbale apraksie ook verkry word.

\section{METODE}

\section{DOELSTELLINGS}

- Om te bepaal of daar 'n neiging tot 'n konstante KVpersentasie oor drie herhalings van dieselfde woord is by ' $n$ proefpersoon om intraproefpersoonkonstantheid te bepaal.

- Om te bepaal of daar 'n neiging tot 'n konstante KVpersentasie bestaan in KVK- en KVKK-eenhede waar die KV dieselfde samestelling het.

- Om te bepaal wat die invloed van verskillende vokale op die $\mathrm{KV}$-persentasie is in KVKK-eenhede met dieselfde inisiële konsonant en eindkonsonantkombinasie.

- Om te bepaal hoe die apraktiese spreker vergelyk met die normale ten opsigte van bogenoemde.

\section{PROEFPERSOONSELEKSIE}

Vier Afrikaanssprekende volwassenes (2 mans en 2 vrouens) wat geen geskiedenis het van spraak-, gehoor- of neurologiese afwykings nie, is geselekteer. Die apraktiese proefpersoon wat geselekteer is, is 'n 43-jarige Afrikaanssprekende man met normale gehoor wat voldoen aan die kriteria vir die seleksie van 'n proefpersoon met verworwe verbale apraksie soos voorgestel deur Kent en Rosenbek (1983). Die kriteria is: (a) probeer-en-tref

\section{${ }^{*} \mathrm{KV}=\mathrm{Konsonant-yokaal}$}

KVK = Konsonant-vokaal-konsonant

KVKK = Konsonant-vokaaI-konsonantkombinasie artikulatoriese soekbewegings en pogings tot selfkorreksie, (b) disprosodie sonder uitgebreide periodes van normale ritme, klem en intonasie, (c) foutonkonstantheid by herhaalde produksie van dieselfde uiting en (d) duidelike probleme met inisiasie van 'n uiting. Drie jaar en 4 maande het verloop nadat die proefpersoon 'n serebro-vaskulêre insident gehad het.

\section{MATERIAAL}

Die toetsmateriaal wat geselekteer is, is betekenisvolle Afrikaanse woorde of eenhede wat saamgestel is volgens die fonotaktiese reëls van Afrikaans. Dit bestaan uit die segmente KVK en KVKK. Die materiaal bestaan uit 4 groepe woorde, naamlik:

1. /sat; san; sent; sent/

2. Kat; kan; kant; kant/

3. Lfak; filli falk; folk/

4. /pak; pal; palk/

\section{APPARAAT EN PROSEDURE}

Opname van die spraaksein is gedoen in 'n klankdigte eenheid met behulp van 'n Nakamichi 550 stereo bandopnemer en 'n omnidireksionele mikrofoon. Die normale sprekers is gevra om die toetsmateriaal drie maal deur te lees. Die apraktiese spreker moes die woorde agter die ondersoeker aan herhaal totdat 3 korrekte produksies van 'n woord verkry is. Die woorde is in 'n toevallig geselekteerde volgorde aangebied. Die sprekers is daarop gewys dat die woorde duidelik maar sonder onnatuurlike klem op enige deel daarvan uitgespreek moet word. Daar is nie gebruik gemaak van 'n aanvangsfrase nie aangesien die apraktiese spreker dit nie kon lees of herhaal nie en eenvormigheid in die prosedure sover moontlik verkry moes word.

Vir die ontleding van die spraaksein is die visuele korrelaat daarvan op 'n Hewlett-Packard 1200 B-tipe ossilloskoop vertoon Senheiser HD 40-oorfone is gebruik sodat die ondersoeker die visuele en ouditiewe sein kon vergelyk. Elke segment van 'n toetswoord is afsonderlik gemeet. Deur dieselfde woord by al die proefpersone direk na mekaar te analiseer, is gepoog om die metingsbetroubaarheid te verhoog. Sodoende is groter konstantheid ten opsigte van die punt van aanvang en eindiging van 'n segment verkry en is dieselfde segmente met dieselfde amplitudeinstelling gemeet

\section{RESULTATE EN BESPREKING}

1. KONSONANT-VOKAAL AS PERSENTASIE VAN TOTALE DUUR OOR DRIE HERHALINGS VAN DIESELFDE WOORD BY DIE NORMAALSPREKENDE INDIVIDU

Die statistiese metode van meervoudige variansie-ontleding is gebruik om die resultate te verwerk en die bespreking te rig.

Tabel 1 Statistiese data met betrekking tot die konstantheid van die $K V \%$ oor 3 herhalings van dieselfde woord by ' individu (kolommefaktor soos verkry deur meervoudige variansie-ontleding)

\begin{tabular}{|l|c|c|c|c|}
\hline $\begin{array}{c}\text { Woord- } \\
\text { groepe }\end{array}$ & $\begin{array}{c}\text { Kolomme- } \\
\text { faktor }\end{array}$ & $5 \%$ peil & $1 \%$ peil & $\begin{array}{c}\text { Vryheids- } \\
\text { grade }\end{array}$ \\
\hline $\begin{array}{l}\text { 1. /sat; san; } \\
\text { sant; sent/ }\end{array}$ & 0,11 & 3,40 & 5,61 & 2 en 24 \\
$\begin{array}{l}\text { 2. /kat; kan; } \\
\text { kant; kant/ }\end{array}$ & 1,09 & 3,40 & 5,61 & 2 en 24 \\
$\begin{array}{l}\text { 3. /fak; fal; } \\
\text { falk; folk } ; \\
\text { 4. /pak; pal; } \\
\text { palk/ }\end{array}$ & 1,58 & 3,40 & 5,61 & 2 en 24 \\
\hline
\end{tabular}


Volgens Tabel $\mathbf{I}$ is die F-verhouding van die kolommefaktor in die woordgroep /sat; san; sant; sent/, 0,11. Hierdie waarde wys op onbeduidende verskille ten opsigte van $\mathrm{KV}$ as persentasie van totale tydsduur omdat die kleiner is as 3,40 (5\% peil) en 5,61 (1\% peil) met 2 en 4 vryheidsgrade. Dieselfde tendens word ook by die drie ander woordgroepe waargeneem. Die feit dat elke woord drie keer herhaal word by ' $n$ individu, lewer nie statisties beduidende verskille op ten opsigte van $\mathrm{KV}$ as persentasie van totale tydsduur nie. Daar bestaan dus wel 'n neiging tot 'n konstante KVpersentasie oor drie herhalings van dieselfde woord by ' $n$ individu. Intraproefpersoonkonstantheid kom dus voor.

Die feit dat daar wel 'n neiging tot ' $n$ konstante $K V$-persentasie oor drie herhalings van dieselfde woord is, impliseer dat temporale kompensasie wel binne ' $\mathrm{KV}$-lettergreep in KVK- en KVKKwoorde in Afrikaans by die proefpersone voorkom en bydra tot hierdie neiging. Daar kom, met ander woorde, minder variasie in die duurpersentasie van die lettergreep as in die duurpersentasie van die segmente waaruit die lettergreep bestaan, voor. DiSimoni (1974b) het die ontwikkeling van temporale kompensasie bestudeer by kinders met die ouderdomme 3, 6 en 9 jaar. Hy vind dat temporale kompensasie eers na 9 jaar ten volle aangeleer is en dit dui dus daarop dat daar ontwikkeling plaasvind tot 'n volwasse, gesofistikeerde, akkurate, tydreëlmeganisme. Sharkey en Folkins (1985) hipotetiseer ook dat verskillende ont wikkelende motoriese prosesse die varieerbaarheid van spraak beïnvloed op verskillende ouderdomme en dat variasie afneem met ouderdom.

By die volwasse Afrikaanssprekende proefpersone kom daar dus 'n intrapersoonlike temporale reël met betrekking tot konstante $\mathrm{KV}$-persentasie oor drie herhalings van dieselfde woord voor. Daar moet egter in gedagte gehou word dat hierdie konstantheid nie absoluut is nie. Daar kom wel 'n geringe mate van variasie voor omdat daar motories-ekwivalente bewegingspatrone bestaan in spraak (Sharkey en Folkins, 1985). Die grense van variasie is egter baie kleiner by die volwassene as by die kind.

\section{KONSTANTHEID VAN KONSONANT-VOKAAL AS PERSENTASIE VAN} TOTALE DUUR IN 'N KVK- EN KVKK-EENHEID

Volgens Tabel 2 is die F-verhouding van die ryefaktor vir die woordgroep /sat; san; sant, вent/, 7,07. Hierdie waarde wys op beduidende verskille tussen die woorde binne die groep ten opsigte van die $\mathrm{KV}$ as persentasie van totale duur omdat dit groter is as 3,49 ( $5 \%$ peil) en 5,95 ( $1 \%$ peil) met 3 en 12 vryheidsgrade. Dieselfde tendens word ook by die woordgroepe / kat; kan; kant; kent/ en /fak; fal; falk; folk/ waargeneem (sien Tabel 2). By die woordgroep /pak; pal; palk/ is die F-verhouding van die

Tabel 2: Statistiese data met betrekking tot $K V$ as persentasie van totale duur in KVK- en KVKK-eenhede (ryefaktor soos verkry deur meervoudige variansie-ontleding)

\begin{tabular}{|c|c|c|c|c|}
\hline $\begin{array}{l}\text { Woord- } \\
\text { groepe }\end{array}$ & Ryefaktor & $5 \%$ peil & $1 \%$ peil & $\begin{array}{l}\text { Vryheids- } \\
\text { grade }\end{array}$ \\
\hline 1. /sat; $\operatorname{san} ;$ & 7,07 & 3,49 & 5,95 & 3 en 12 \\
\hline $\begin{array}{l}\text { 2. /kat; kan; } \\
\text { kant; kənt }\end{array}$ & 25,62 & 3.49 & 5,95 & 3 en 12 \\
\hline $\begin{array}{l}\text { 3. /fak; fal; } \\
\text { falk; folk }\end{array}$ & 5,67 & 3,49 & $\begin{array}{c}5,95 \\
\text { (nie bedui- } \\
\text { dend op die } \\
1 \% \text { peil nie) }\end{array}$ & 3 en 12 \\
\hline $\begin{array}{l}\text { 4. /pak; pal; } \\
\text { palk/ }\end{array}$ & 2,81 & \multicolumn{2}{|c|}{$\begin{array}{c}\text { (nie statisties beduidend } \\
\text { nie) }\end{array}$} & 2 en 9 \\
\hline
\end{tabular}

ryefaktor egter 2,81 wat kleiner is as 4,26 (5\% peil) en 8,02 (1\% peil) met 2 en 9 vryheidsgrade. Daar is egter wel 'n verskil in die KV-persentasie, alhoewel hierdie verskil dan nie statisties beduidend is soos by woordgroepe een tot drie nie.

Uit bogenoemde resultate blyk dit dus dat daar nie by die proefpersone ' $n$ neiging is tot ' $n$ konstante KV-persentasie in ' $n$ KVKen KVKK-eenheid nie. Die temporale reël in Engels, naamlik dat die duur van die KV in 'n KVK- en 'n KVKK-eenheid ongeveer dieselfde bly in verhouding tot die totale duur ten spyte van die feit dat die KV in KVK twee derdes en in KVKK in werklikheid die helfte van die totale uiting uitmaak (Walsch 1984), kom dus nie by die Afrikaanse proefpersone voor nie. Uit Walsch (1984) se studie blyk dit dat in uitinge wat volgens die fonotaktiese reëls van Engels saamgestel is, byvoorbeeld /s ps/ en /s pst/, daar soveel konsonantkombinasieverkorting plaasvind, dat die KV-persentasie /s / vir albei uitinge $\pm 50 \%$ is en dus neig om konstant te bly. Hierdie verskynsel kom egter nie by die Afrikaanse proefpersone voor nie. Vir proefpersoon 1 was die persentasie vir $/ \mathrm{sa} /$ in /sat/ byvoorbeeld $68,14 \%$ teenoor die $51,25 \%$ vir $/ \mathrm{sa} / \mathrm{in} / \mathrm{sant} /$. Konsonantkombinasieverkorting vind dus nie in so 'n mate plaas dat $\mathrm{die} / \mathrm{nt} / \mathrm{in} / \mathrm{sant} / \mathrm{dieselfde}$ persentasie beslaan as die/t/ in /sat/ nie. Konsonantkombinasieverkorting kom egter wel in Afrikaans voor, byvoorbeeld vir proefpersoon 1 was die gemiddelde duur van die /t/ in /sat/ $137 \mathrm{~ms}$ terwyl die /t/ in /sant/, $100 \mathrm{~ms}$ was. Waar die doel van konsonantkombinasieverkorting in Engels volgens Walsch en Parker )1982) dus is om vasgestelde duurverhoudinge te behou vir die KV-gedeelte in KVK- en KVKKeenhede, blyk dit nie die geval te wees by die Afrikaanse proefpersone nie.

3. DIE INVLOED VAN VERSKILLENDE VOKALE OP DIE KV PERSENTASIE IN KVKK-EENHEDE MET DIESELFDE INISIËLE KONSONANT EN EINDKONSONANTKOMBINASIE

Uit Tabel 3 blyk dit dat die gemiddelde persentasie van $/ \mathrm{sa} / \mathrm{en} / \mathrm{s}$ $\mathrm{V}$ in kombinasie met die konsonantkombinasie/nt/ nie noemenswaardig van mekaar verskil nie (slegs met $0,50 \%$ ). Daar kan dus afgelei word dat dit 'n normale spreker \pm dieselfde tyd neem om $/ \mathrm{sa} /$ en $/ \mathrm{ac} / \mathrm{te}$ produseer. Die gemiddelde persentasie van $/ \mathrm{fa} /$ in kombinasie met $/ \mathrm{k} /$ is $2,94 \%$ meer as vir $/ / \mathrm{fo} /$ ' en die afleiding kan dus gemaak word dat dit die normale spreker effens langer neem om $/ \mathrm{fa} /$ as $/ \mathrm{fo} /$ te produseer. Vir die produksie van $/ \mathrm{ka} /$ en $\mathrm{ke} / \mathrm{in}$ kombinaise met $/ \mathrm{nt} /$ is die gemiddelde persentasie $5,78 \%$ meer vir $/ \mathrm{ka} /$ as vir $/ \mathrm{ko} /$. Dit neem dus die normale spreker $5,78 \%$ langer om $/ \mathrm{ka} /$ in kombinasie met $/ \mathrm{nt} /$ te produseer as om $\mathrm{sa} /$ in dieselfde kombinasie te produseer. Dit wil dus voorkom asof die vokaal wel 'n geringe invloed op die KV-persentasie van totale duur het.

Tabel 3: Vergelyking ten opsigte van $K V$ as persentasie van totale duur by woorde met dieselfde samestelling, waar slegs die vokaal gevarieer word

KV-persentasie (van die toetswoorde)

\begin{tabular}{|c|c|c|c|c|c|c|}
\hline & /sant/ & /aent/ & fiant & fient/ & $/$ Palk & $/$ Polk/ \\
\hline & 51,25 & 48,56 & \begin{tabular}{l|l}
1 & 34,41
\end{tabular} & 27,35 & $\begin{array}{lll}1 & 43,63\end{array}$ & 43.62 \\
\hline & \begin{tabular}{l|l}
2 & 55,30
\end{tabular} & 4 & \begin{tabular}{|l|l|}
2 & 39,1 \\
\end{tabular} & 1 & \begin{tabular}{l|l}
2 & 5 \\
\end{tabular} & 10 \\
\hline & \begin{tabular}{l|l}
3 & 55,06
\end{tabular} & 31 & \begin{tabular}{|l|l}
3 & 37,98
\end{tabular} & 37 & \begin{tabular}{|l|l|}
3 & 56,51
\end{tabular} & 52,33 \\
\hline & \begin{tabular}{l|l}
4 & 61,63
\end{tabular} & 4,00 & \begin{tabular}{l|l}
4 & 38,40
\end{tabular} & 81 & \begin{tabular}{l|l}
4 & 57,45
\end{tabular} & 55,05 \\
\hline & \begin{tabular}{l|l}
$*$ & 55,81
\end{tabular} & $\overline{56,32}$ & 37,49 & 1,71 & $\overline{46}$ & 50,52 \\
\hline & \begin{tabular}{c|c|}
5 & 69,31
\end{tabular} & 65,77 & \begin{tabular}{l|l|l}
5 & 53,44
\end{tabular} & 42,03 & \begin{tabular}{l|l|l}
5 & 65,30
\end{tabular} & 61,53 \\
\hline
\end{tabular}

* Gemiddelde KV \% vir normale pp e

The South African Journal of Communication Disorders, Vol. 33, 1986 
Die gemiddelde persentasie vir normale proefpersone van $/ \mathrm{sa} /$ en Die gemid $(55,18 \%$ en $56,32 \%)$ in kombinasie met $/ \mathrm{n} /$ is aansienlik 列 $31,71 \%$ ) in kombinasie met $/ \mathrm{nt} /$. Die persentasie wat $/ \mathrm{n} t /$ beslaan van die totale woordduur word dus bepaal deur die klankamgewing waarin dit voorkom. Soos daar dus in Engels die temporale reël bestaan dat vokale langer is voor 'n stemhebbende as in stemlose konsonant (House \& Fairbanks en Peterson \& Lehiste aangehaal deur DiSimoni (1974b)) kan daar gesê word dat daar'n temporale reël by die Afrikaanse proefpersone bestaan, naamlik dat ' $n / s /$ plus 'n vokaal 'n groter persentasie van die woord uitmaak as ' $n / k$ / plus ' $n$ vokaal wanneer dit geproduseer word voor die konsonantkombinasie /nt/. Konsonantkombinasieverkorting moet dus in 'n groter mate inwerk op /nt/ wanneer dit voorafgegaan word deur ' $n$ kontinuant plus 'n vokaal, as deur ' $n$ plosief plus ' $n$ vokaal. Die verkorting van die duur van 'n konsonant in ' $n$ konsonantkombinasie moet in antisipasie van die volgende konsonant uitgevoer word (Walsch \& Parker 1982). Hierdie verkorting moet dus op grond van 'n temporale reël wat verband hou met die klankomgewing beplan word.

4. VERGELYKING VAN DIE PRODUKSIE VAN DIE APRAKTIESE SPREKER MET DIE VAN DIE NORMALE PROEFPERSONE

Die z-waarde vir die drie herhalings van elke woord wat deur die apraktiese spreker geproduseer is, is bereken en word voorgestel deur Figure 1.1 tot 1.15. Uit al die grafieke blyk dit duidelik dat daar onkonstantheid is in die herhaalde produksie van dieselfde woord by die apraktiese spreker in teenstelling met die konstantheid wat by normale sprekers voorkom (sien 1). Daar bestaan ook nie konstantheid ten opsigte van die kurwe van elke grafiek nie en verskeie tendense word waargeneem. Uit figure 1.1, 1.7 en $1.12 \mathrm{kan}$ waargeneem word dat daar met herhaalde produksie nader beweeg word aan die normale produksie. Adaptasie vind dus plaas. Figure 1.2, 1.8 en 1.15 toon aan dat die laaste herhaling wel die naaste aan die normale produksie is, maar dat daar nie geleidelike adaptasie voorkom nie. Uit figure 1.11 en 1.13 word waargeneem dat die eerste produksie die naaste aan die normale was terwyl daar met die tweede en derde produksie eers weg en toe weer nader aan die normale produksie beweeg is.

Figuur 1.10 is die enigste grafiek wat aantoon dat met die produksie van /fal/ daar met elke herhaling verder weg beweeg is van die normale produksie. Figure 1.6 en 1.14 toon aan dat die eerste produksie die verste van normále produksie is en dat daar met die tweede produksie nader daaraan beweeg word. Die derde produksie is egter weer swakker. Die tendens wat die meeste voorkom is dié in figure $1.3,1.4,1.5$ en 1.9 , waar die beste produksie op die tweede herhaling en die swakste produksie op die derde herhaling voorkom.

Die eerste twee tendense kan aanduidend wees van adaptasie met herhaalde produksie wat ' $n$ kenmerkende simptoom van apraksie is (Darley, Aronson en Brown 1975). Die ander tendense is slegs'n weerspieëling van die onkonstante produksie van die apraktiese spreker.
FIGUUR 1: GRAFIESE VOORSTELLING VAN DIE ZWAARDE BY DIE APRAKTIESE SPREKER.

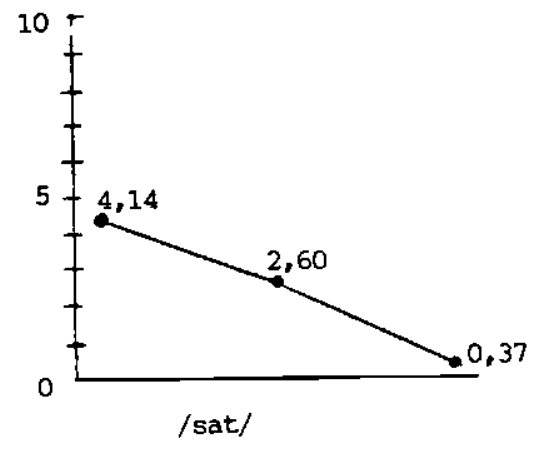

Figuur 1.1

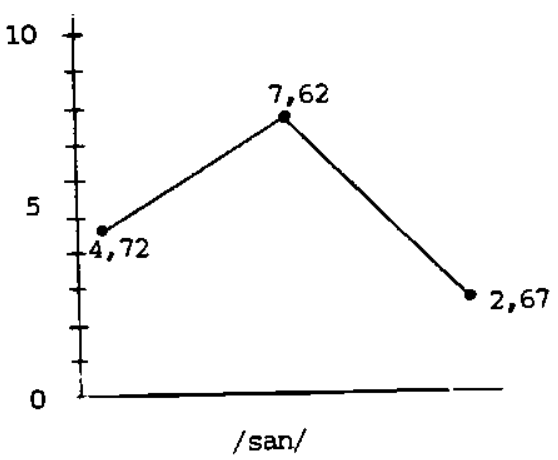

Figuur 1.2

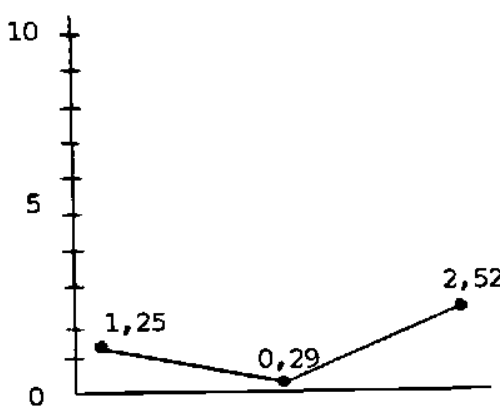

/ssnt/

Figuur 1.3

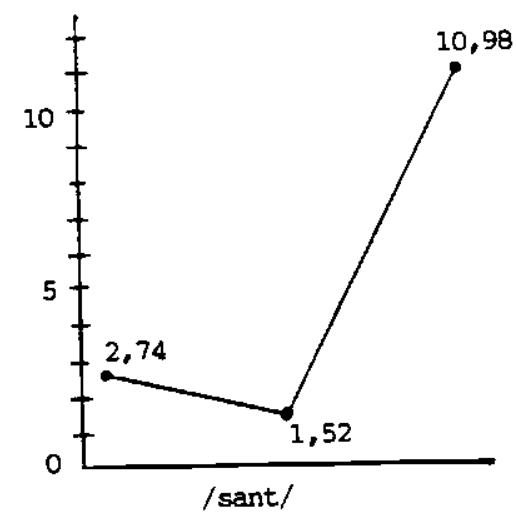

Figuur 1.4 


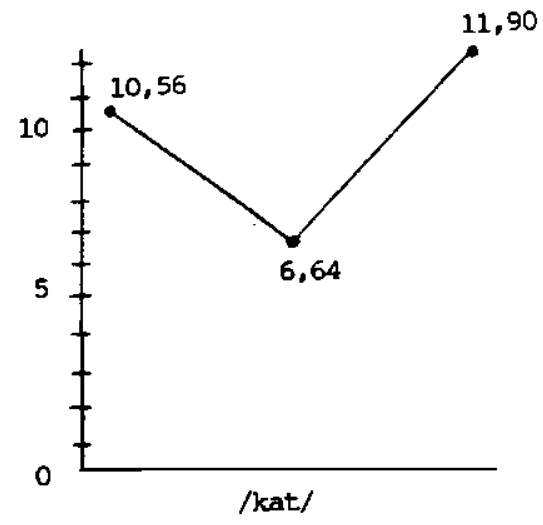

Figuur 1.5

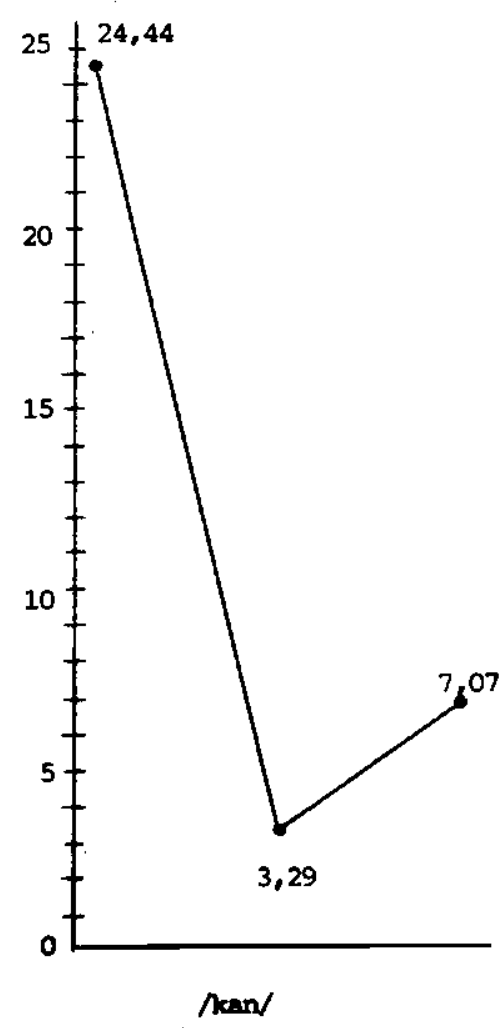

Figuur 1.6

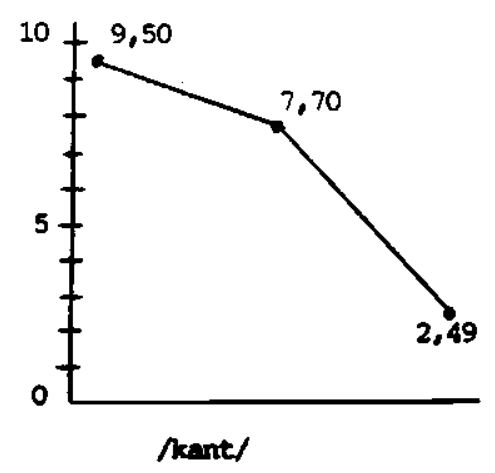

Figuur 1.7

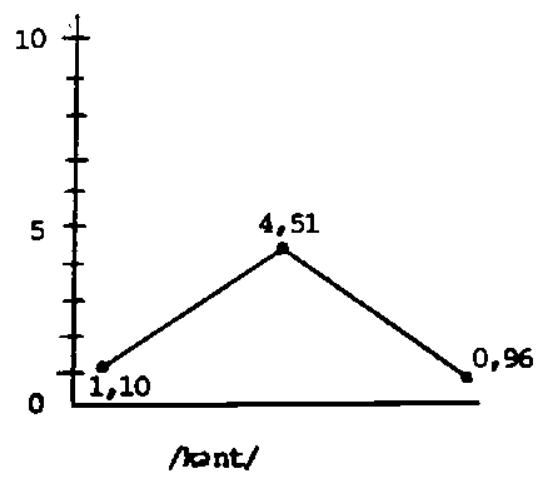

Figuur 1.8

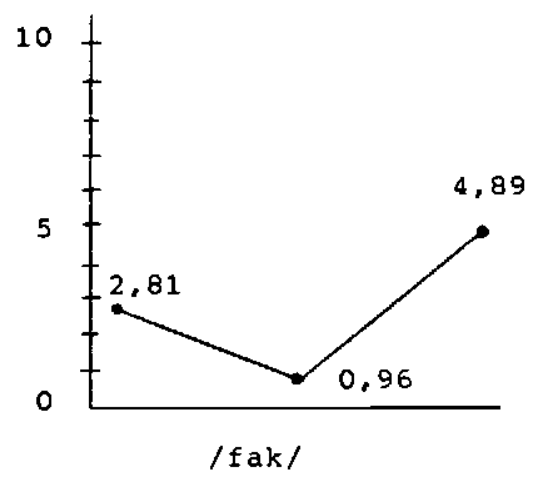

Figuur 1.9

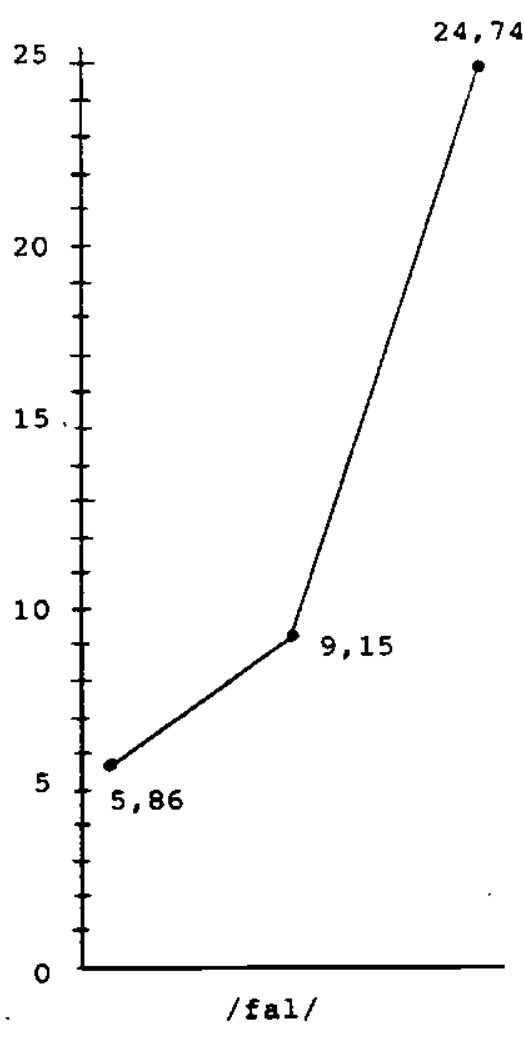

Figuur 1.10

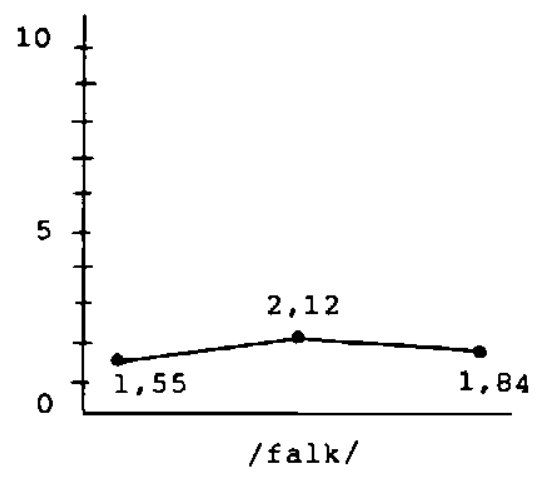

Figuur 1.11

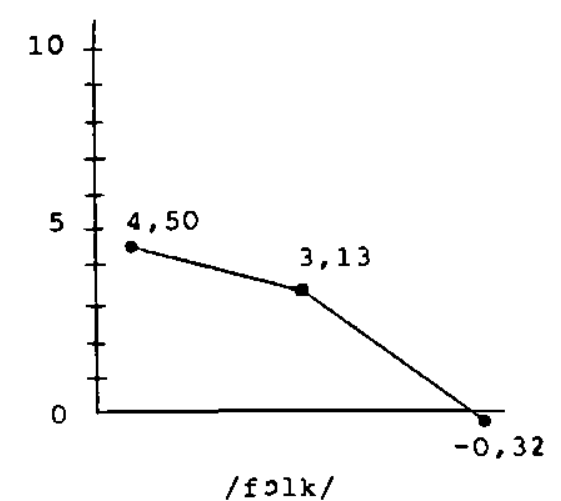

Figuur 1.12

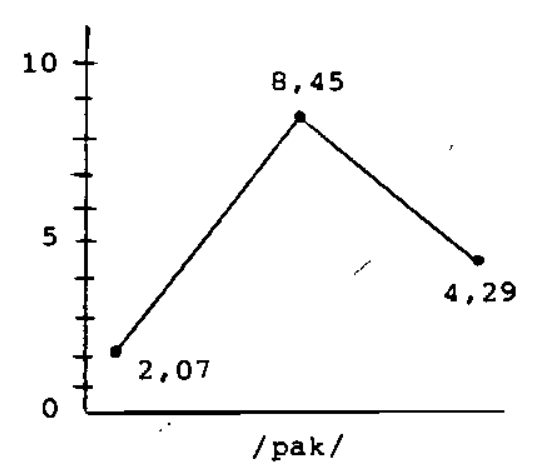

Figuur 1.13 


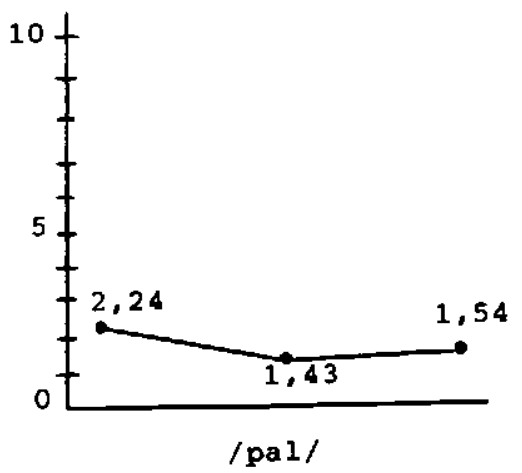

Figuur 1.14

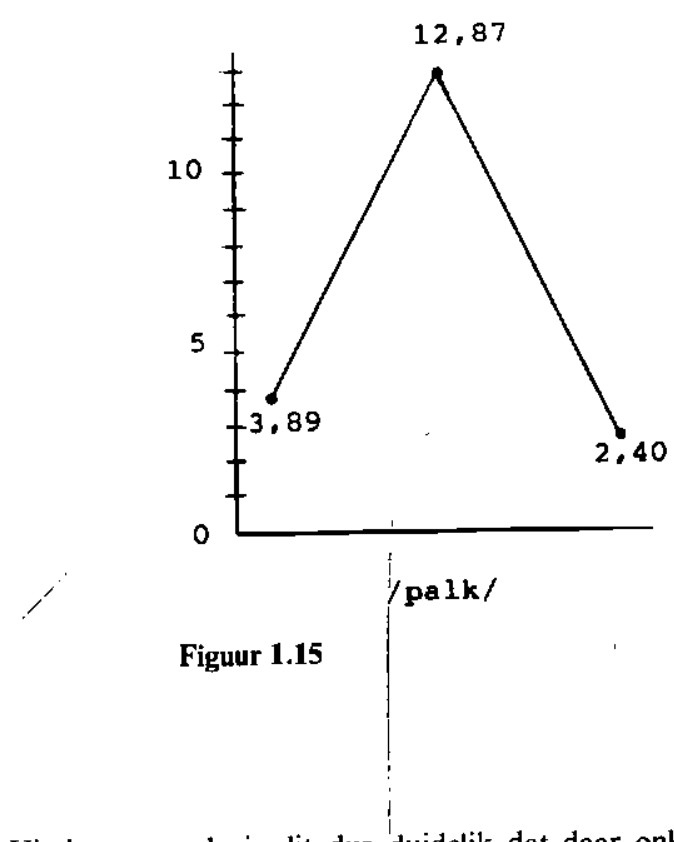

Uit bogenoemde is dit dus duidelik dat daar onkonstantheid bestaan ten opsigte van die segmentele tydsduur in die herhaalde produksie van 'n woord deur die proefpersoon met verbale apraksie. Onkonstantheid en variasie van die foutpatroon oor herhalings van dieselfde woord is een van die klinies mees waarneembare en kenmerkende eienskappe van apraktiese spraak (Kent \& Rosenbek, 1983). In teenstelling daarmee produseer die normale spreker elke herhaling met bykans dieselfde duur vir elke segment.

'n Verdere verskynsel wat waargeneem word, is dat die z-waarde van die verskillende woorde soos geproduseer deur die apraktiese spreker, verskil. Die $z$-waarde is aanduidend van die mate waarin 'n produksie van die normale afwyk. Volgordelike rangskikking van die $z$-waardes is moontlik en word voorgestel in Tabel 4. Die afleiding wat moontlik hieruit gemaak kan word, is dat hoe hoër die z-waarde is, hoe meer afwykend is die produksie en dat die moeilikheidsgraad van die produksie van die verskillende woorde varieer by die apraktiese spreker. Deur die afleiding te maak dat ' $n$ moeilike produksie meer afwykend sal wees as 'n makliker produksie, kan daar op grond van die z-waardes bepaal word watter spesifieke produksies vir die spesifieke spreker makliker of moeiliker is, byvoorbeeld vir die woorde// $/ 01 \mathrm{k} / \mathrm{en} / \mathrm{falk} /$ is die gemiddelde z-waardes onderskeidelik 7,31 en 1,83 . Daar kan nie regstreeks gesê word dat dit vir die apraktiese spreker makliker is om 'n $/ \mathrm{a} / \mathrm{as} / / \mathrm{o} /$ te produseer nie want $z$-waarde $\mathrm{vir} / \mathrm{fal} /$ is 13,25 wat dus weer hoër is as die z-waarde vir / $/$ olk/.

Tabel 4: Volgordelike rangskikking van die mate waarin geproduseerde woorde van die apraktiese spreker afwyk van die normale soos aangedui deur die $\mathrm{z}$-waarde van elke produksie.

\begin{tabular}{|c|c|}
\hline Toetswoord & z-waarde \\
\hline$/ \mathrm{fal} /$ & 13,25 \\
\hline$/$ kan/ & 11,60 \\
\hline /kat/ & 9,70 \\
\hline$/ \mathrm{p} 01 \mathrm{k} /$ & 7,31 \\
\hline / kant/ & 6,56 \\
\hline /palk/ & 6,38 \\
\hline$/$ sant & 5,08 \\
\hline$/ \operatorname{san} /$ & 5,00 \\
\hline$/ \mathrm{pak} /$ & 4,93 \\
\hline$/ \mathrm{fak} /$ & 2,88 \\
\hline /sat/ & 2,37 \\
\hline Kant/ & 2,19 \\
\hline$/$ falk & 1,83 \\
\hline$/ \mathrm{pal}$ & 1,73 \\
\hline /sent/ & 1,35 \\
\hline
\end{tabular}

Daar kan wel afgelei word dat dit vir hierdie spreker makliker is om ' $n / a$ / te produseer in kombinasie met ' $n$ inisiële $/ f /$ en finale $/ \mathrm{k} /$ as wat dit vir hom is om 'n $/ \% /$ te produseer in dieselfde klankomgewing. Hierdie feit ondersteun die stelling dat persone met verbale apraksie dikwels probleme ondervind met 'n spesifieke klank wanneer dit in 'n spesifieke klankomgewing voorkom (Van der Merwe, 1985). Deur gebruik te maak van hierdie metode van ontleding waarin die z-waarde vir elke produksie addisioneel tot ouditiewe analise van simptome bepaal word, kan daar dus met groter akkuraatheid vasgestel word presies waar die spesifieke pasiënt se probleem lê. Veral in 'n gevorderde stadium van terapie kan so 'n analise waardevolle terapieleidrade verskaf.

Die onkonstantheid ten opsigte van $\mathrm{KV}$ as persentasie van totale duur by herhaling van dieselfde woord deur die apraktiese spreker word verder geillustreer deur Tabel 5 . Hierin word aangetoon dat die gemiddelde konstantheidsvariasie vir proefpersone 1 tot 4 onderskeidelik $3,43 \% ; 3,97 \% ; 4,29 \%$ en $4,13 \%$ is. Die normale omvang is dus $3,43 \%$ tot $4,29 \%$ en die gemiddelde konstantheidsvariasie-persentasie vir die normale proefpersone is $3,95 \%$. By die apraktiese spreker is die gemiddelde konstantheidsvariasiepersentasie $10,97 \%$ wat dus ver buite die normale omvang en baie hoër as die gemiddeld van die normale is. Dit dui dus daarop dat daar groter variasie is ten opsigte van die $\mathrm{KV}$-persentasie van totale duur by herhaling van dieselfde woord deur die apraktiese spreker as by die normale spreker. Hierdie variasie ten opsigte van $\mathrm{KV}$ as persentasie van totale duur dui weer eens op die onkonstantheid en variasie in die produksies van die apraktiese spreker.

Onkonstantheid en variasie is egter ook kenmerkend van kinderspraak. Sharkey en Folkins (1985) haal DiSimoni (1974b) en Tingley en Allen (1975) se studies aan waarin gevind is dat die varieerbaarheid van baie van die parameters van spraak afneem met ouderdom tot by puberteit. Nadat 'n kind geleer het om 'n taak suksesvol uit te voer, word die onderliggende motorprosesse verfyn deur verhoogde antisiperende komponente van die 
Tabel 5: Vergelyking tussen die normale sprekers en die apraktiese spreker ten opsigte van KV\%-konstantheid oor 3 herhalings van dieselfde woord. Voorstelling deur middel van konstantheidsvariasie-waardes.

\begin{tabular}{|c|c|c|c|c|c|c|}
\hline \multirow{16}{*}{ 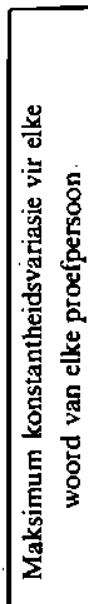 } & Woorde & \begin{tabular}{|c|} 
Proef- \\
persoon 1
\end{tabular} & $\begin{array}{c}\text { Proef- } \\
\text { persoon } 2\end{array}$ & $\begin{array}{c}\text { Proef- } \\
\text { persoon } 3\end{array}$ & \begin{tabular}{|c|} 
Proef- \\
persoon 4
\end{tabular} & ${ }^{*} \mathrm{AP}$ \\
\hline & sat & 1,68 & 0,87 & 7,86 & 0,76 & 6,16 \\
\hline & $\operatorname{san}$ & 4,95 & 1,93 & 0,96 & 3,11 & 11,66 \\
\hline & sant & 4,60 & 2,91 & 1,05 & 8,95 & 12,64 \\
\hline & sent & 0,5 & 4,02 & 0,25 & 2,15 & 13,64 \\
\hline & kat & 3, & 6,77 & 1,66 & 3,69 & 3,87 \\
\hline & kan & 1,82 & 3,37 & 1,40 & 4,92 & 14,35 \\
\hline & kant & 0,78 & 2,71 & 2,27 & 2,69 & 19,28 \\
\hline & $\mathrm{k} n t$ & 4,82 & 4,68 & 2,68 & 9,63 & 9,98 \\
\hline & fak & 4,29 & 2,53 & 23,02 & 0,56 & 12,86 \\
\hline & fal & 5,92 & 6,14 & 0,71 & 4,74 & 5,20 \\
\hline & falk & 6,28 & 6,73 & 5,17 & 3,76 & 7,99 \\
\hline & folk & 3,02 & 3,74 & 3,76 & 4,65 & 23,08 \\
\hline & pak & 3,08 & 10,61 & 1,70 & 5,42 & 4,20 \\
\hline & pal & 3,2 & 0,81 & 3,38 & 3,88 & 11,35 \\
\hline & palk & 2,91 & 1,76 & 8,55 & 3,11 & 8,32 \\
\hline \multicolumn{2}{|c|}{$\begin{array}{l}\text { Gemiddelde kon- } \\
\text { stantheidsvariasie } \\
\text { vir elke proef- } \\
\text { persoon }\end{array}$} & $3,43 \%$ & $3,97 \%$ & $4,29 \%$ & $4,13 \%$ & $10,97 \%$ \\
\hline \multicolumn{7}{|c|}{ Omvang van normale konstantheidsvariasie } \\
\hline \multicolumn{7}{|c|}{ Gemiddelde konstandheidsvariasie-persentasie vir normale } \\
\hline
\end{tabular}

${ }^{*} \mathrm{AP}=$ Apraktiese proefpersoon.

bewegingskema, deur meer ekonomiese gebruik van energie en deur minder variasie by die herhaling van 'n taak (Sharkey \& Folkins, 1985). Di Simoni (1974b) het byvoorbeeld gevind dat kinders eers na 9 jaar die temporale reël van temporale kompensasie aanleer, met ander woorde, verfyning geskied ook op die gebied van tydreëling. Dit wil dus voorkom asof hierdie beheer weer verlore gaan by die apraktiese spreker en resulteer in onkonstantheid in die toepassing van tydreëling. Dit is dus moontlik om die afleiding te maak dat tydreëlingvariasie wat in apraktiese spraak voorkom, ooreenstemming kan toon met die tydreëlingvariasie in die spraakproduksie van kinders. Waar die kind nog nie volkome beheer cor tydreëling ontwikkel het nie, het die apraktiese spreker moontlik weer die beheer verloor. Kent en Forner (1980) stel ook voor dat groter variasie in kinderspraak verband kan hou met die feit dat hulle spraak stadiger is as die van volwasse spraak en dat stadige spraak predisponerend is tot verhoogde tydreëlingsfoute.

Stadige produksie is ook kenmerkend van apraktiese spraak (Kent \& Rosenbek, 1983) en kan dus saam met foutiewe programmering die oorsaak wees van die variasie in die - toepassing van tydreëling by die apraktiese spreker.

In die produksie van die aprakties spreker word dieselfde tendens as by die normale spreker waargeneem, naamlik dat ' $n$ kontinuant plus 'n vokáal in kombinasie met /nt/'n groter KV. persentasie het as 'n ploffer plus 'n vokaal in kombinasie met / nt/ (sien Tabel 3). Daar kan dus afgelei word dat hierdie temporale reël by hierdie spesifieke apraktiese spreker behoue gebly het.
Tabel 6 toon verder aan dat die KV-persentasie van dieselfde woord baie groter is by die apraktiese spreker as by die normale sprekers. Byvoorbeeld vir die woord / kat/ is die KV-persentasie vir die apraktiese spreker gemiddeld $65 \%$ en vir die normale sprekers slegs $44,30 \%$. Uit die roudata was dit duidelik dat segmentele tydsduur oor die algemeen baie langer is by die apraktiese spreker as by die normale sprekers. Hierdie verlengde segmentele tydsduur resulteer dus in stadiger produksie. Dit is egter ook opvallend dat die vokaal in elke woord heelwat meer verleng word as die konsonante in dieselfde woord. Dit bevestig Kent en Rosenbek (1983) se bevindings dat vokaalverlenging en stadige produksie kenmerkend is van apraktiese spraak. Die hoë $\mathrm{KV}$-persentasie wat voorkom by die apraktiese spreker is dus die gevolg van die oormatige verlenging van die vokaal. Die persentasie wat die KK uitmaak van die totale duur van die woord is dus nou korter by die apraktiese spreker as by die normale sprekers. Dit moet egter nie geïnterpreteer word as dat die apraktiese spreker die KK vinniger produseer nie. Die duur in millisekondes van die $\mathrm{KK}$ is steeds langer as die normale duur. Die persentasie wat dit van die totale woordduur uitmaak, is egter kleiner omdat die $\mathrm{KV}$-gedeelte, as gevolg van oormatige vokaalverlengings, so 'n groot persentasie van die totale woordduur beslaan.

Tabel 6: Vergelyking tussen normale sprekers en 'n apraktiese spreker ten opsigte van die $\mathrm{KV}$-persentasie

\begin{tabular}{|l|c|c|c|}
\hline Woorde & $\begin{array}{c}\text { Omvang van KV- } \\
\text { persentasie by } \\
\text { normale sprekers }\end{array}$ & $\begin{array}{c}\text { Gemiddelde KV- } \\
\text { persentasie vir die } \\
\text { normale sprekers }\end{array}$ & $\begin{array}{c}\text { KV-persentasie } \\
\text { by die apraktiese } \\
\text { spreker }\end{array}$ \\
\hline /sat/ & $63,75-68,74$ & 67,13 & 72,59 \\
/san/ & $61,21-68,40$ & 64,80 & 78,92 \\
/sant/ & $51,25-61,63$ & 55,81 & 69,31 \\
/sent/ & $48,56-64,00$ & 56,33 & 65,77 \\
/kat/ & $41,90-45,90$ & 44,30 & 65,00 \\
/kan/ & $46,86-52,62$ & 49,56 & 69,80 \\
/kant/ & $34,41-39,18$ & 37,49 & 53,44 \\
/kənt/ & $27,35-38,81$ & 31,71 & 42,03 \\
/fak/ & $54,56-61,30$ & 57,79 & 67,33 \\
/fal/ & $62,06-63,63$ & 62,78 & 81,33 \\
/falk/ & $43,63-57,45$ & 53,54 & 65,36 \\
/folk/ & $43,62-55,05$ & 50,52 & 61,53 \\
/pak/ & $39,81-49,51$ & 45,55 & 60,39 \\
/pal/ & $28,12-57,01$ & 48,36 & 71,14 \\
/palk/ & $31,00-37,89$ & 35,46 & 51,32 \\
\hline
\end{tabular}

Alhoewel die produksie van die apraktiese spreker uitermate verleng word relatief tot normale produksie en dus dui op afwykende programmering van segmentele tydsduur, demonstreer verskeie studies dat duurverhoudings wel behoue bly by hierdie sprekers. Collins, Rosenbek en Wertz (1983) bestudeer die verhouding tussen vokaal- en woórdduur by normale en apraktiese sprekers in langerwordende woorde. Die resultate toon dat die vokaal korter word in verhouding met die duur van die basiswoord namate die woord langer word by die normale en by die apraktiese sprekers.

Collins et al. (1983) haal ook vir Freeman, Sands en Leavitt aan wat demonstreer dat die Engelse fonologiese reël, naamlik dat vokale langer is voor' $n$ stemhebbende as voor 'n stemlose konsonant, ook toegepas word deur apraktiese sprekers.

Uit bogenoemde kan daar dus afgelei word dat sekere aspekte van temporale programmering, byvoorbeeld segmentele tydsduur, 
afwykend is by die apraktiese spreker terwyl ander, byvoorbeeld duurverhoudinge, intakt is.

\section{GEVOLGTREKKINGS}

\section{MET BETREKKING TOT DIE NORMALE SPREKERS}

- Daar bestaan 'n neiging tot 'n konstante KV-persentasie oor drie herhalings van dieselfde woord by ' $n$ individu. Hierdie konstantheid is egter nie absoluut nie omdat daar motoriesekwivalente bewegingspatrone in spraak bestaan. Hieruit kan ook afgelei word dat temporale kompensasie wel by Afrikaanssprekende proefpersone voorkom en bydra tot die neiging van 'n konstante KV-persentasie oor herhalings van dieselfde woord.

- Daar bestaan nie 'n neiging tot ' $n$ konstante KV-persentasie in KVKK-eenhede byvoorbeeld /sat/ teenoor/sant/ nie. Die temporale reël in Engels, naamlik dat die duur van die $\mathrm{KV}$ in 'n KVK- en KVKK-eenheid ongeveer dieselfde bly in verhouding tot die totale duur (Walsh 1984), kom dus nie by die Afrikaanssprekende proefpersone voor nie. Konsonantkombinasieverkorting kom dus in 'n mindere mate in Afrikaans voor as byvoorbeeld in Engels en dus nie met die doel om vasgestelde duurverhoudinge te behou nie.

-Verskillende vokale het 'n geringe invloed op die $\mathrm{KV}$ persentasie van die totale duur van KVKK-eenhede met dieselfde inisiële konsonant en eindkonsonantkombinaise. Die KV-persentasie word dus bepaal deur dieklankomgewing waarin dit voorkom. Uit die toetsmateriaal kan afgelei word dat daar ' $n$ temporale reël in Afrikaans bestaan, naamlik dat 'n kontinuant plus 'n vokaal 'n groter persentasie van die woord uitmaak as 'n ploffer plus 'n vokaal wanneer dit geproduseer word voor die konsonantkombinasie /nt/.

\section{MET BETREKKING TOT DIE APRAKTIESE SPREKER}

- Deur ontleding van ' $n$ apraktiese spreker se spraak in terme van segmentele tydsduur en die bepaling van 'n z-waarde vir elke produksie, kan daar in 'n groot mate bepaal word met watter klanke in watter spesifieke klankomgewing die spreker die meeste probleme het. Deur hierdie metode van analise addisioneel tot ouditiewe ańalise van apraktiese simptome toe te pas, kan waardevolle terapieleidrade veral in 'n gevorderde stadium van behandeling verkry word.

- Daar bestaan onkonstantheid en variasie van die foutpatroon ten opsigte van segmentele tydsduur in die herhaalde produksie van ' $n$ woord by die apraktiese proefpersoon.

- Daar bestaan onkonstantheid ván die KV-persentasie met die herhaling van dieselfde woord. Daar is dus groter variasie ten opsigte van die KV-persentasie by herhaling van dieselfde woord deur die apraktiese spreker as by die normale spreker.

- Variasie van tydreëling in die produksie van die apraktiese spreker kan moontlik verband hou met die tydreëlingsvariasie in kinderspraak.

- Die temporale reël wat by normale sprekers voorkom, naamlik dat 'n kontinuant plus 'n vokaal in kombinasie met /nt/'n groter KV-persentasie het as 'n ploffer plus 'n vokaal in kombinasie met /nt/, het behoue gebly by hierdie apraktiese spreker.

- Die KV-persentasie by die apraktiese spreker is deurgaans groter as vir die normale sprekers en dit bevestig Kent en
Rosenbek (1983) se bevindinge, naamlik dat vokaalverlenging en stadige produksie kenmerkend is van apraktiese spraak.

Aangesien hierdie slegs in eerste poging was om die programmering en toepassing van tydreëling in Afrikaans te bestudeer, bestaan daar nog 'n groot behoefte aan verdere kennis en navorsing op hierdie gebied.

\section{BEDANKINGS}

Die skryfster wil graag mev. A. van der Merwe, Departement Spraakheelkunde en Oudiologie, Universiteit van Pretoria, bedank vir haar leiding met die uitvoer van die studie waarop hierdie artikel gegrond is.

\section{VERWYSINGS}

Bell-Berti, F. en Harris, K.S. A temporal model of speech production. Phonetica, 38, 9-20, 1981.

Collins, M.; Rosenbek, J.C. en Wertz, R.T. Spectrographic analysis of vowel and word duration in apraxia of speech. Journal of Speech and Hearing Research, 26, 224-230, 1983.

Cooper, M.H. en Allen, G.D. Timing control accuracy in normal -speakers and stutterers. Journal of Speech and Hearing Research, 20, 55-71, 1977.

Darley, F.L.; Aronson, A.E. \& Brown, J.R. Motor Speech Disorders. W.B. Saunders Company, Philadelphia, 1975.

DiSimoni, F.G. Influence of consonant environment on duration of vowels in the speech of three, six, and nine-year old children. J. Acoust. Soc Am, 55, 362-363, 1974a.

DiSimoni, F.G. Some preliminary observations on temporal compensation in the speech of children. J. Acoust. Soc. Am, 56, $697-699,1974 b$.

DiSimoni, F.G. Evidence for a theory of speech production based on observations of the speech of children. J. Acoust. Soc. Am, $56,1919-1921,1974 \mathrm{c}$.

DiSimoni, F.G. en Darley, F.L. Effect on phoneme duration control of three utterance length conditions in an apraxic patient. Journal of Speech and Hearing Disorders, 42, 257-264, 1977.

Kent, R.D. en Forner, L.L. Speech segment durations in sentence recitations by children and adults. Journal of Phonetics, 8, 157$168,1980$.

Kent, R.D. en Rosenbek, J.C. Prosodic disturbance and neurologic lesion. Brain and Language, 15, 159-192, 1982.

Kent, R.D. en Rosenbek, J.C. Acoustic patters of apraxia of speech. Journal of Speech and Hearing Research, 26, 231-249, 1983.

Löfqvist, A. en Yoshioka, H. Interarticular programming in obstruent production. Phonetica, 21-34, 1981.

Sharkey, S.G. en Folkins, J.W. Variability of lip and jaw movements in children and adults: Implication for the development of speech motor control. Journal of Speech and Hearing Research, 8-15, 1985.

Tingley, B.M. en Allen, G.D. Development of speech control in children. Child Development, 46, 186-194, 1975.

Van der Merwe, A. Terapieprogram vir verbale ontwikkelingsapraksie met toepassingsmoontlikhede vir ander spraakafwykings, Pretoria: Universiteit van Pretoria, 1985.

Walsch, T, Modelling temporal relations within English syllables. Journal of Phonetics, 12, 19-35, 1984.

Walsch, T. en Parker, F. Vowel length and "voicing" in a following consonant. Journal of Phonetics, 9, 305-308, 1981.

Walsch, T. en Parker, F. Consonant cluster abbreviation: an abstract analysis. Journal of Phonetics, 10, 423-437, 1982. 


\section{ADVANCED FOR TOMORROW. THE MAICO MA41}

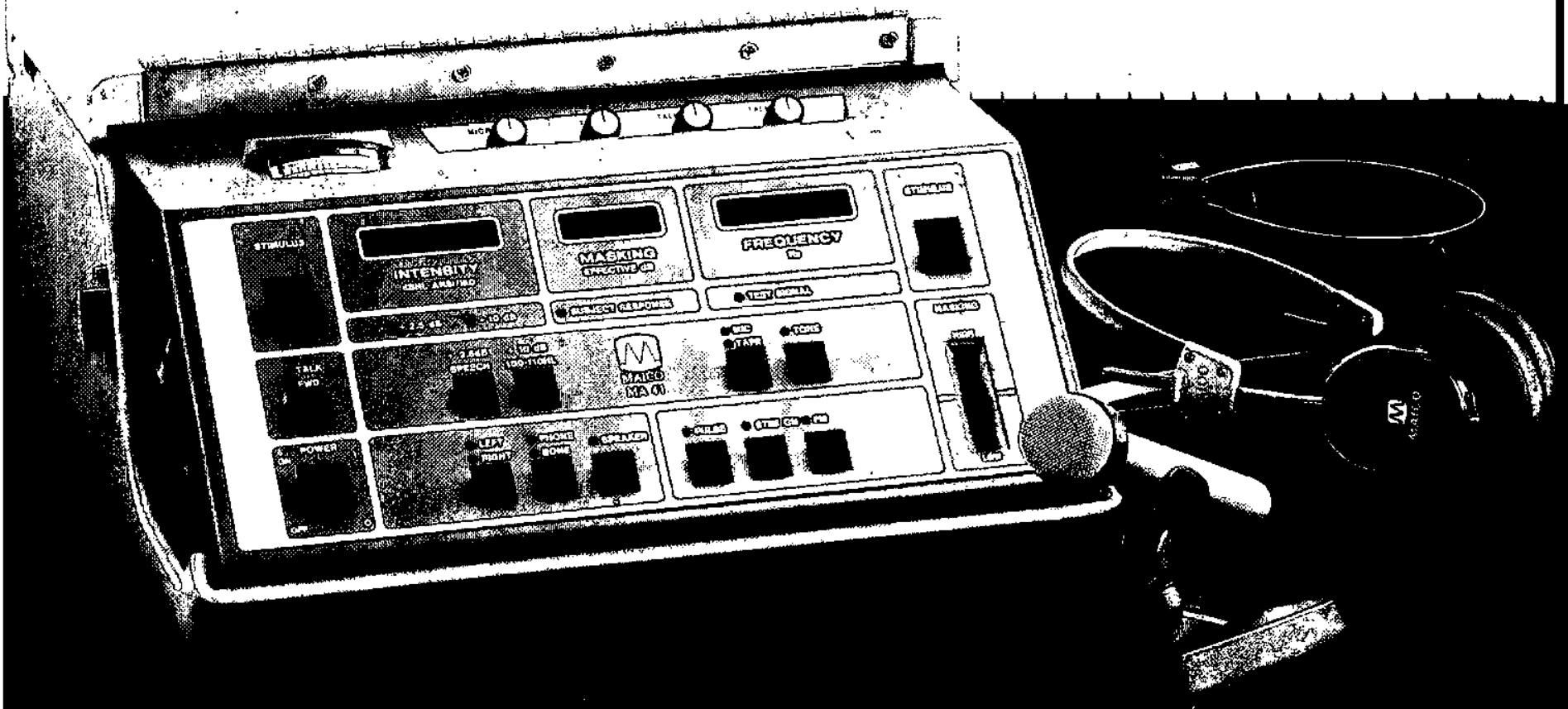

\begin{tabular}{|c|c|c|c|}
\hline $\begin{array}{l}\text { FEATURE } \\
\text { COMPARISONS }\end{array}$ & WO & (6) & $\begin{array}{c}\text { MA } \\
41\end{array}$ \\
\hline Air Conduction. & - & 4 & \\
\hline $\begin{array}{l}\text { Air Conduction with } \\
\text { Bone and Masking. }\end{array}$ & & $s$ & \\
\hline $\begin{array}{l}\text { Air Conduction } \\
\text { with Bone, Speech } \\
\text { and Masking. }\end{array}$ & & & \\
\hline
\end{tabular}

The Needler-Westdene Organlsation (Pty) Lid P O Box 28975, Sandringham, 2131

Tel (011) 643-5017 changing to 485-1302/5
Progressive. The latest technology. Built to meet tomorrow's needs head-on.

\section{That's the Maico MA41.}

It's a portable audiometer with reliable circuitry and features that you require in an office audiometer. Like speech and narrow band masking, talk forward and talk back, and the new $\mathrm{B} 71$ bone vibrator.

The MA41 is sophisticated enough for all applications, yet it's remarkably easy to use. So you can concentrate on your patient. Not the machine.

The Maico MA41. A top-of-the-line portable that's advanced for tomorrow ... but available today.

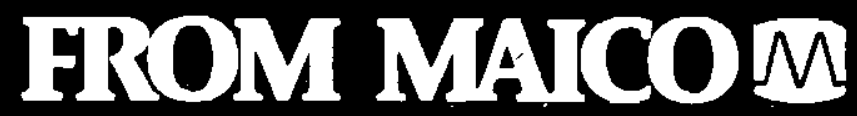

